\title{
PENURUNAN PERILAKU KEKERASAN ORANGTUA PADA ANAK USIA SEKOLAH MELALUI LATIHAN ASERTIF
}

\author{
Abdul Gowi ${ }^{1,2^{*}}$, Achir Yani S. Hamid ${ }^{3}$, Tuti Nuraini ${ }^{3}$ \\ 1. STIKES Kharisma Karawang, Karawang 41316, Indonesia \\ 2. Program Studi Magister Fakultas Ilmu Keperawatan Universitas Indonesia, Depok 16424, Indonesia \\ 3. Fakultas Ilmu Keperawatan Universitas Indonesia, Depok 16424, Indonesia \\ *Email:abdul.gowi@gmail.com
}

\begin{abstract}
Abstrak
Penelitian ini bertujuan untuk memperoleh gambaran pengaruh latihan asertif terhadap perilaku kekerasan orang tua pada anak usia sekolah di Kabupaten Karawang. Sampel pada kelompok intervensi dan kontrol masing-masing 32 orang. Latihan asertif dilakukan selama 6 sesi. Hasil penelitian menunjukkan terjadi peningkatan kemampuan komunikasi asertif orangtua pada kelompok intervensi dibanding kelompok kontrol secara bermakna $(\mathrm{p}<0,05)$. Kemampuan anak dalam mengendalikan emosi pada kelompok intervensi meningkat, sedangkan pada kelompok kontrol menurun secara bermakna $(p<0,05)$. Latihan asertif membantu orangtua menurunkan perilaku kekerasan pada anak melalui komunikasi asertif. Terapi ini direkomendasikan pada orangtua, guru, dan pemberi pelayanan kesehatan.
\end{abstract}

Kata kunci: kemampuan komunikasi asertif orangtua, latihan asertif, mengendalikan emosi

\begin{abstract}
This research aimed to describe the influence of assertive training on violence behavior of parents towards children in Karawang district. Samples in the intervention group and control were 64 parents, 32 respondent for each group. Assertive training has conducted in 6 sessions. The results showed increased assertive communication skills of parents on the group that received assertive training. There was significant difference among those groups $(p<0.05)$. The group of parents who did not receive assertive training, showed a significant decreased communication of skills $(p<0.05)$. The was increased ability of children in controlling their emotions of intervention group parents, while there was significant decreased children ability of control group parents $(p<0.05)$. Assertive training was proven to decrease parents'violent behaviors towarsd children. It was recommended that this training to be regularly conducted to parents, teachers, and health care provider.
\end{abstract}

Keywords: parent's assertive comunication ability, assertive training, managing emotions

\section{Pendahuluan}

Kedudukan dan fungsi suatu keluarga dalam kehidupan manusia mempunyai sifat primer dan fundamental, pada hakekatnya merupakan wadah pembentukan bagi anggotanya, terutama anak-anak yang masih berada dalam bimbingan dan tanggung jawab orangtuanya. Perkembangan anak meliputi keadaan fisik, emosional sosial, dan intelektual (Yusuf, 2009). Anak usia sekolah dikenal dengan fase industri versus rasa rendah diri, merupakan masa anak memasuki dunia sekolah, dimana tumbuh rasa kemandirian anak, ingin terlibat dalam tugas yang dapat dilakukan sampai dengan selesai (Erikson, 1950 dalam Wong, Hockenberry, Wilson, Winkelstein, \& Schwartz, 2009). Orangtua bertanggung jawab terhadap pemenuhan kebutuhan anak, yang juga berperan sebagai guru pertama dan berperan penting dalam pembentukan sikap, kepercayaan, nilai, dan tingkah laku anak. Peran orangtua harus dapat berubah dan beradaptasi dengan perubahan yang terjadi sejalan dengan perkembangan anak melalui beberapa tahapan perkembangan, dari tahap anak sampai mencapai tahap dewasa dan setiap tahap tugas perkembangan harus dicapai. Pada anak usia sekolah, untuk dapat diterima lingkungan sosialnya, anak harus mampu melaksanakan tugas perkembangan sesuai yang diharapkan, sehingga tidak mengalami kesulitan.

Ketidakmampuan orangtua mengontrol emosi membuat anak menjadi temperamental bersifat dan sikap buruk. Akibatnya, orangtua tidak menjadi model baik dalam mengontrol dan mengasuh anak. 
Fenomena perlakuan salah dan tidak wajar adalah permasalahan yang dihadapi anak-anak, yang dapat terjadi di lingkungan keluarga, komunitas, sekolah, maupun tempat bermain. Child abuse diartikan sebagai perbuatan semena-mena orang yang seharusnya menjadi pelindung bagi seorang anak secara fisik, seksual, dan emosi. Dari batasan tersebut umumnya pelaku adalah orang terdekat dengan si anak (Sugiarno, 2008). Menurut Hamid (2009), yang mendefinisikan perlakuan salah pada anak adalah segala perlakuan terhadap anak yang akibatnya mengancam kesejahteraan dan tumbuh kembang anak, baik secara fisik, psikologi sosial, maupun mental. Karakteristik pendidikan dan umur orangtua mempunyai pengaruh dalam mendidik anak. Huraerah (2006) menyatakan kekerasan yang terjadi pada anak dapat dipengaruhi oleh tingkat pendidikan orangtua yang rendah, belum matang secara psikologis, ketidaktahuan dalam mendidik anak, harapan orangtua yang tidak realistis pada anak, faktor sosiokultural, stres anak, keluarga, orangtua, dan situasi pencetus lainnya.

Kekerasan pada anak menjadi salah satu ancaman paling nyata di dunia anak, pelaku adalah orang yang dikenal baik anak. Usia korban berusia 6-15 tahun. Sebanyak 50\% korban kekerasan dalam rumah tangga (KDRT) di Jawa Barat merupakan anak-anak di bawah usia 18 tahun. Berdasarkan data, 9,27\% kasus kekerasan anak dilakukan ibu kandung dan 5,85\% ayah kandung. Persentase kekerasan tersebut menunjukkan tingginya angka kekerasan pada anak yang dilakukan orangtua atau dalam keluarga di Indonesia. Namun, sebenarnya masih banyak kasus yang terbungkus persepsi masyarakat, meletakkan masalah kekerasan pada anak sebagai persoalan domestik rumah tangga yang sangat sensitif dan latar belakang budaya yang kuat yang tidak pantas untuk diekspos.

Perlakuan salah pada anak akan berpengaruh pada gangguan psikologis, anak terlihat murung, tertutup, jarang beradaptasi dan bersosialisasi, kurang konsentrasi, serta prestasi akademik menurun (Hefler, 1999). Menurut Moore dalam Nataliani (2004), yang menjelaskan bahwa efek tindakan dari korban penganiayaan fisik, anak menjadi negatif dan agresif, serta mudah frustasi; ada yang menjadi sangat pasif dan apatis; ada yang tidak mempunyai kepribadian sendiri; ada yang sulit menjalin hubungan dengan individu lain; dan ada pula yang timbul rasa benci yang luar biasa terhadap dirinya sendiri.

Peningkatkan kemampuan komunikasi secara positif yang dilakukan orangtua masih dirasakan kurang, karena tidak diberikan contoh model dan latihan tersendiri untuk melatih keterampilan tersebut. Selain itu, tidak ada feedback terhadap latihan keterampilan komunikasi orangtua, apakah yang dilakukan sudah benar atau tidak (Ramadhani, 2008). Untuk itu, diperlukan suatu latihan tentang cara berkomunikasi asertif di rumah, yaitu orangtua dapat meningkatkan kemampuan mengendalikan emosi sehingga perlakuan salah pada anak dapat diminimalisir. Latihan tersebut harus dilakukan berulang-ulang dan diterapkan orangtua pada anak, sehingga memerlukan bimbingan dan arahan secara intensif dari seorang terapis (Safaria, 2009), dalam bentuk latihan asertif (Towsend \& Mary, 2009).

\section{Metode}

Penelitian ini menggunakan metode intervensi semu (Quasi experimental), dengan rancangan prepost test with control group dengan intervensi latihan asertif. Penelitian ini akan melakukan observasi perilaku kekerasan orangtua terhadap anak sebelum dan sesudah eksperimen (Arikunto, 2009). Dalam rancangan ini terdapat kelompok kontrol (pembanding) yang memungkinkan peneliti melihat perubahan-perubahan yang telah terjadi setelah adanya intervensi (Hasan, 2004). Penelitian untuk mengetahui perbedaan kemampuan orangtua dalam berkomunikasi asertif terhadap perilaku kekerasan pada anak usia sekolah sebelum dan sesudah dilakukan latihan asertif. Hal ini bertujuan membandingkan kemampuan orangtua dalam berkomunikasi asertif terhadap perilaku kekerasan pada anak usia sekolah pada kelompok kontrol dan intervensi. Uji reabilitas dapat dilihat pada nilai Cronbach's Alpha dengan nilai korelasi 0,987. 
Tabel 1. Perbedaan Kemampuan Komunikasi Asertif Orangtua antara Kelompok Intervensi dan Kontrol

\begin{tabular}{|c|c|c|c|c|c|c|c|c|c|}
\hline Aspek & Kelompok & $\mathbf{N}$ & Mean & SD & SE & $\mathbf{T}$ & df & $\mathbf{p}$ & $95 \%$ CI \\
\hline Kognitif & $\begin{array}{l}\text { Intervensi } \\
\text { Kontrol }\end{array}$ & $\begin{array}{l}32 \\
32\end{array}$ & $\begin{array}{l}68,59 \\
38,38\end{array}$ & $\begin{array}{l}4,744 \\
5,066\end{array}$ & $\begin{array}{l}0,839 \\
0,895\end{array}$ & $-24,630$ & 62 & 0,000 & $-32,671 ;-27,766$ \\
\hline Psikomotor & $\begin{array}{l}\text { Intervensi } \\
\text { Kontrol }\end{array}$ & $\begin{array}{l}32 \\
32\end{array}$ & $\begin{array}{l}48,00 \\
26,84\end{array}$ & $\begin{array}{l}3,341 \\
3,502\end{array}$ & $\begin{array}{l}0,591 \\
0,619\end{array}$ & $-24,726$ & 62 & 0,000 & $-22,867 ;-19,446$ \\
\hline Afektif & $\begin{array}{l}\text { Intervensi } \\
\text { Kontrol }\end{array}$ & $\begin{array}{l}32 \\
32\end{array}$ & $\begin{array}{l}41,19 \\
23,06\end{array}$ & $\begin{array}{l}2,867 \\
3,068\end{array}$ & $\begin{array}{l}0,507 \\
0,542\end{array}$ & $-24,414$ & 62 & 0,000 & $-19,609 ;-16,641$ \\
\hline $\begin{array}{l}\text { Komposit } \\
\text { kemamp uan } \\
\text { orangtua }\end{array}$ & $\begin{array}{l}\text { Intervensi } \\
\text { Kontrol }\end{array}$ & $\begin{array}{l}32 \\
32\end{array}$ & $\begin{array}{c}157,78 \\
88,28\end{array}$ & $\begin{array}{l}10,952 \\
11,636\end{array}$ & $\begin{array}{l}1,937 \\
2,056\end{array}$ & $-24,590$ & 62 & 0,000 & $-32,671 ;-16,641$ \\
\hline
\end{tabular}

\section{Hasil}

Karakteristik orangtua antara kelompok intervensi dan kontrol sebelum mendapatkan latihan asertif adalah sama/homogen $(\mathrm{p}>0,05)$. Uji kesetaraan kemampuan orangtua dalam berkomunikasi asertif menggunakan analisis $t$-test independent, terdapat perbedaan yang kurang bermakna $(\mathrm{p}>0,05)$.

Tabel 1 menunjukkan bahwa ada perbedaan yang bermakna ( $p=0,000 ; \alpha=0,05)$. Selisih keseluruhan kemampuan komunikasi asertif orangtua pada kelompok intervensi menunjukkan kenaikan skor kemampuan setelah mendapat latihan asertif sebesar 63,34\%. Sedangkan pada kelompok kontrol hasil menunjukkan kenaikan skor kemampuan setelah diberikan terapi generalis sebesar 6,53\%. Selisih perbedaan kemampuan komunikasi asertif orangtua, pada kelompok intervensi lebih tinggi dibanding kelompok kontrol secara bermakna $(\mathrm{p}=$ $0,000 ; \alpha=0,05)$.

Tabel 2 menunjukkan bahwa ada perbedaan selisih kemampuan kognitif orangtua, dimana kelompok intervensi lebih tinggi secara bermakna dibanding dengan kelompok kontrol $(p=0,000 ; \alpha=0,05)$. Hasil penelitian pada tabel 3 menunjukkan bahwa kemampuan anak mengendalikan emosi pada kelompok intervensi lebih tinggi secara bermakna dengan perbedaan sebesar 28,53 ( $\mathrm{p}=0,000 ; \alpha=$ $0,05)$. Hasil penelitian menunjukkan bahwa selisih perbedaan kemampuan anak dalam mengendalikan emosi pada kelompok intervensi lebih tinggi secara bermakna dibandingkan dengan kelompok kontrol $(p=0,000 ; \alpha=0,05)$ (lihat pada tabel 4).

\section{Pembahasan}

Kemampuan kognitif antara kelompok intervensi dan kontrol telah homogen dan berada dalam rentang sedang, sebelum dilakukan latihan asertif. Uji kesetaraan terhadap kedua kelompok tidak ada perbedaan bermakna rerata tingkat kemampuan kognitif di kedua kelompok. Kelompok intervensi menunjukkan peningkatan kemampuan kognitif lebih tinggi secara bermakna $(p<0,05)$ dibanding kelompok kontrol yang menunjukkan penurunan secara bermakna $(\mathrm{p}<0,05)$. Hal tersebut disebabkan pemahaman yang kurang, sedikit minat membaca materi yang sudah didapat dan kesibukan orangtua dalam mengurus keluarga, rentang waktu cukup lama antara pre-test, pelaksanaan terapi generalis dan post-test kurang lebih 4 minggu dibanding pada kelompok intervensi. Ketika kesadaran diri sudah timbul, namun tidak dikembangkan menyebabkan individu mengalami ketidakmampuan mengambil keputusan, berperilaku tidak sesuai yang dapat membahayakan bagi kesejahteraan fisik dan psikis anggotanya (Stuart \& Laraia, 2005).

Latihan asertif mendukung orangtua memahami dan menanggapi segala jenis respon emosi yang dimunculkan anak akibat dari kebutuhan anak yang tidak terpenuhi (Emmons, dalam Towsend, 2009). Dengan latihan asertif, orangtua melatih menerima emosi diri sendiri, menerima emosi anak, serta memikirkan dengan aktif cara merespon emosi anak. Orangtua akan memahami bahwa dengan cara agresif atau pasif setiap menghadapi keluhan anak tidak membawa dampak positif hubungan orangtua dan anak (Gottman \& DeClaire, 2008). 
Tabel 2. Selisih Perbedaan Kemampuan Komunikasi Asertif Orangtua Sebelum dan Sesudah Latihan Asertif pada Kelompok Intervensi dan Kontrol

\begin{tabular}{llcccccccc}
\hline \multicolumn{2}{c}{ Kemampuan } & N & Mean & SD & SE & t & df & p & $\mathbf{9 5 \%}$ CI \\
\hline Kognitif & Intervensi & 32 & 27,53 & 5,946 & 1,051 & $-21,168$ & 62 & 0,000 & $-33,141 ;-27,422$ \\
& Kontrol & 32 & $-2,75$ & 5,489 & 0,970 & & & & \\
\multirow{2}{*}{ Psikomotor } & Intervensi & 32 & 19,28 & 4,137 & 0,731 & $-21,428$ & 62 & 0,000 & $-23,267 ;-19,296$ \\
& Kontrol & 32 & $-2,00$ & 3,802 & 0,672 & & & & \\
\multirow{2}{*}{ Afektif } & Intervensi & 32 & 16,53 & 3,574 & 0,632 & $-21,503$ & 62 & 0,000 & $-20,015 ;-16,610$ \\
& Kontrol & 32 & $-1,78$ & 3,230 & 0,571 & & & & \\
\multirow{2}{*}{$\begin{array}{l}\text { Komposit } \\
\text { selisih }\end{array}$} & Intervensi & $\mathbf{3 2}$ & $\mathbf{6 3 , 3 4}$ & $\mathbf{1 3 , 6 5 7}$ & $\mathbf{2 , 4 1 4}$ & & & & \\
\hline
\end{tabular}

Perbedaan selisih kemampuan kognitif orangtua berkomunikasi asertif pada kelompok intervensi lebih tinggi secara bermakna $(\mathrm{p}<0,05)$ dibanding kelompok kontrol. Penelitian oleh Purwandari dan Purwanti (2008), peningkatan kecerdasan emosi anak melalui pelatihan pembentukan karakter anak oleh guru di sekolah menunjukkan pengaruh yang bermakna $(p=0,05)$. Sesuai penelitian Novianti (2010), yang menjelaskan adanya pengaruh yang bermakna $(p<0,05)$ terapi kelompok assertiveness training terhadap kemampuan komunikasi asertif ibu dalam mengelola emosi anak. Penelitian ini memperkuat hasil penelitian yang dilakukan pada orangtua dengan latihan asertif. Terjadi peningkatan kognitif pada orangtua setelah latihan asertif, meliputi pemahaman mengenai gaya komunikasi asertif, kemampuan membedakan gaya komunikasi asertif, agresif, dan pasif yang selama ini dilakukan oleh orangtua kepada anak usia sekolah.

Kelompok yang mendapatkan pelatihan asertif menunjukkan peningkatan kemampuan psikomotor lebih tinggi secara bermakna $(p<0,05)$ dibanding dengan kelompok kontrol. Komunikasi asertif membutuhkan latihan bertahap dan berulang untuk mencapai kemampuan komunikasi asertif. Ada pun tahap dalam setiap sesinya antara lain, yaitu describing (menggambarkan perilaku baru yang akan dipelajari), learning (mempelajari perilaku baru melalui demonstrasi terapis), practicing atau role play (mempraktekkan kembali perilaku baru di dalam kelompok), feedback (pemberian masukan atau penilaian dari terapis), dan implementation (melatih perilaku yang dipelajari ke situasi nyata di rumah bersama dengan anak).

Kunci keberhasilan latihan asertif bagi orangtua adalah kemampuan menjadi pendengar yang aktif, membutuhkan waktu hanya 5-10 menit untuk mendengar keluhan anak dengan penuh perhatian, mata sejajar dengan anak, berhadapan, rileks/ santai, dan menahan diri untuk memberikan nasihat ke anak. Kelompok intervensi menunjukkan ada peningkatan kemampuan afektif orangtua dalam berkomunikasi asertif lebih tinggi secara bermakna $(p<0,05)$ dibandingkan kelompok kontrol. Hasil penelitian menunjukkan peningkatan kemampuan anak mengendalikan emosi lebih tinggi secara bermakna pada kelompok intervensi $(p<0,05)$.

Kemampuan anak dalam mengendalikan emosi sebelum orangtua mendapatkan latihan asertif ternyata sudah berada pada rentang kemampuan sedang. Asumsi peneliti adalah anak mendapat lingkungan support system yang adekuat selama menjalankan perannya sebagai anak. Anak tidak hanya meniru orangtuanya di rumah tapi juga guru mereka di sekolah. Seperti yang dikatakan oleh Mubayidh (2007), yang mengungkapkan bahwa guru ikut mendidik murid mengembangkan rasa tanggung jawab pada diri sendiri, mengajarkan menghormati diri sendiri, mengajarkan memberi pertolongan pada temannya, dan membantu beradaptasi pada situasi sulit. 
Tabel 3. Perbedaan Kemampuan Anak Mengendalikan Emosi antara Kelompok Intervensi dan Kontrol

\begin{tabular}{ccccccccc}
\hline Kelompok & N & Mean & SD & SE & T & Df & p & $\begin{array}{c}\text { Mean diff } \\
\mathbf{9 5 \%} \text { CI }\end{array}$ \\
\hline Intervensi & 32 & 101,75 & 4,912 & 0,868 & $-21,902$ & 62 & 0,000 & $\begin{array}{c}28,53 \\
\text { Kontrol }\end{array}$ \\
\hline
\end{tabular}

Kemampuan anak mengendalikan emosi dapat meningkat jika orangtua diberikan pelatihan terlebih dahulu. Untuk merubah perilaku negatif anak di rumah, gaya bicara, menanggapi keluhan anak secara asertif, menjadikan orangtua sebagai contoh peran dalam menyelesaikan masalahnya dicontoh/ditiru anak. Sebaliknya, jika anak tidak dilatih sejak dini, anak akan mengalami kesulitan menyelesaikan masalah sehingga anak cenderung menyelesaikan dalam bentuk perilaku maladaptif (Rosa, 2005). Penelitian Shapiro, et al. (1997 dalam Safaria \& Eka, 2009), memaparkan bahwa anak yang memiliki kemampuan dalam mengendalikan emosi akan lebih mudah menangani masalah yang dihadapi baik di sekolah maupun dalam hubungan dengan temannya. Anak akan lebih percaya diri dalam hubungan sosial dan sukses dalam belajar. Sebaliknya, pada anak yang tidak pernah dilatih, memiliki kemampuan mengendalikan emosi yang rendah dan kurang terampil dalam menangani masalah yang dihadapinya.

Penelitian ini mendukung hasil penelitian yang dilakukan oleh peneliti, dalam hal ini adalah meningkatkan kemampuan mengendalikan emosi anak melalui pelatihan kemampuan kognitif, afektif, dan psikomotor orangtua berkomunikasi secara asertif kepada anak dengan usia sekolah. Setelah dilatih, orangtua menerapkan di rumah sebagai pelatih mengendalikan emosi anak, memberikan contoh cara dalam menyelesaikan masalah kepada anak, dan menjadi pendengar yang baik dan aktif ketika anak mempunyai masalah/ keluhan. Orangtua merupakan orang pertama yang menjadi pusat identifikasi anak dan orang paling banyak menghabiskan waktu, berinteraksi dengan anak sehingga memberi pengaruh terhadap perilaku anak melalui proses belajar dengan melihat, meniru dan melakukan yang dilakukan orangtuanya, anak mengadopsi perilaku orangtua (Hurlock, 2008).
Selisih perbedaan terhadap kemampuan anak dalam mengendalikan emosi pada orangtua yang mendapatkan latihan asertif lebih tinggi secara bermakna $(p<0,05)$ sebanyak $17,22 \%$. Hal ini disebabkan oleh pemberian latihan asertif diikuti dengan cara serius dan bersungguh-sungguh baik pelaksanaan di kelompok maupun latihan di rumah. Adanya komitmen dan keinginan mau berubah serta kemampuan orangtua dalam mengenali permasalahan yang sedang dialami sendiri dan mengendalikan emosi, tidak berbicara dengan anak dalam kondisi emosi, dan mampu menciptakan lingkungan yang aman dan nyaman bagi anak dalam rumah. Begitu juga dengan orangtua yang tidak mendapat latihan asertif, terjadi penurunan sebanyak 1,16\%. Berdasarkan pada hasil observasi buku kerja dan wawancara dengan orangtua, hal ini disebabkan kemampuan yang dimiliki baik dari aspek kognitif, afektif dan psikomotor dalam rentang sedang, suasana yang kondusif dalam rumah, keseriusan berkomitmen meningkatkan kemampuan mengendalikan emosi dan komunikasi terbuka yang dibangun bersama dalam keluarga.

\section{Kesimpulan}

Penelitian tentang penurunan perilaku kekerasan orangtua pada anak usia sekolah melalui latihan asertif menunjukkan bahwa kemampuan orangtua berkomunikasi secara asertif meningkat setelah orangtua mendapat latihan asertif. Latihan asertif efektif meningkatkan kemampuan orangtua dalam menurunkan perilaku kekerasan terhadap anak. Kemampuan anak dalam mengendalikan emosi meningkat setelah orangtua mendapat latihan asertif. Karakteristik orangtua dan latihan asertif berpeluang dalam meningkatkan kemampuan kognitif, afektif, dan psikomotor. Hasil penelitian menunjukkan bahwa kemampuan orangtua dalam berperilaku asertif meningkat $(p=0,000 ; \alpha=0,05)$. 
Tabel 4. Selisih Perbedaan Kemampuan Anak Mengendalikan Emosi Sebelum dan Sesudah Orangtua Mendapat Latihan Asertif pada Kelompok Intervensi dan Kontrol

\begin{tabular}{ccccccccc}
\hline Kelompok & $\mathbf{N}$ & Mean & SD & SE & $\mathbf{T}$ & $\mathbf{D f}$ & $\mathbf{p}$ & $\mathbf{9 5 \%}$ CI \\
\hline Intervensi & 32 & 27,22 & 6,509 & 1,151 & $-21,353$ & 62 & 0,000 & $-31,031 ;-25,719$ \\
Kontrol & 32 & $-1,16$ & 3,760 & 0,665 & & & & \\
\hline
\end{tabular}

Peningkatan upaya promosi kesehatan pada kelompok sehat yang berbasis komunitas sesuai isu kesehatan jiwa di dunia dengan pemberdayaan masyarakat pada generasi penerus bangsa, melalui bidang pelayanan kesehatan jiwa masyarakat sebagai upaya menyehatkan jiwa generasi penerus bangsa dimulai dari kesehatan jiwa keluarga. Melatih perawat puskesmas dan pembentukan kader kesehatan jiwa, meningkatkan sumber swadaya masyarakat, dan menjadikannya misi kesehatan jiwa keluarga sebagai tanggung jawab masyarakat bersama. Menetapkan batasan kerja menjadi tanggung jawab dan wewenang antara kader kesehatan, perawat jiwa puskesmas, dan perawat spesialis keperawatan jiwa (DN, AY, HP).

\section{Referensi}

Arikunto, S. (2009). Prosedur penelitian: Suatu pendekatan praktik. Jakarta: Rineka Cipta.

Emmons, \& Alberti. (1977). Assertiveness: Innovation, explanations, issues, \& impact. San Luis: Impact Publisher.

Gottman, \& DeClaire, J. (2008). Mengembangkan kecerdasan emosional anak (Edisi 1). Jakarta: PT Gramedia Pustaka Utama.

Hamid, A.Y. (2009). Bunga rampai: Asuhan keperawatan kesehatan jiwa. Jakarta: EGC.

Hasan, I. (2004). Analisis data penelitian dengan statistik (Edisi 2). Jakarta: PT Bumi Aksara.

Hefler. (1999). Understanding attitudes \& predicting social behavior. New York: Prentice Hall.

Hurlock, E. (2008). Perkembangan anak jilid 1 (Edisi 6). Jakarta: Erlangga.

Huraerah, A. (2006). Kekerasan terhadap anak. Bandung: PT Nuansa.

Mubayidh, M. (2007). Kecerdasan \& kesehatan emosional anak. Jakarta: Pustaka Al-Kautsar.
Nataliani. (2004). Dampak timbulnya kekerasan pada anak. Diperoleh dari http://duniapsikologi.com.

Novianti, E. (2010). Pengaruh terapi kelompok Assertiveness Training terhadap kemampuan komunikasi ibu dalam mengelola emosi anak usia sekolah (7-12 tahun) di Kelurahan Balumbang Jaya Kota Bogor tahun 2010 (Tesis master, tidak dipublikasikan). FIK UI, Jakarta.

Nurjanah. (2008). Mengembangkan kecerdasan emosi pada anak. Gifted Review jurnal keberbakatan \& kreatifitas, 2 (1), 13-19.

Purwandari, E., \& Purwati. (2008). Character building: pengaruh pendidikan nilai terhadap kecerdasan emosi anak. Jurnal Penelitian Humaniora, 9 (1), $13-31$.

Ramadhani, S. (2008). The art of positive communicating, mengasah potensi, \& kepribadian positif pada anak melalui komunikasi positif (Edisi 1). Yogyakarta: Book Marks.

Rosa, S. (2005). Psikologi perkembangan (Edisi 1). Jakarta: Balai pustaka.

Safaria, T., \& Eka, N.S. (2009). Manajemen Emosi (Edisi 1). Jakarta: PT Bumi Aksara.

Sugiarno. (2008). Aspek klinis kekerasan pada anak dan upaya pencegahannya. Diperoleh dari http// www.lcki.org/images/seminar_anak. pdf.

Stuart, G.W., \& Laraia, M.T. (2005). Principles \& practice of psychiatric nursing (8th Ed.). St. Louis: Mosby.

Townsend, \& Mary. (2009). Psychiatric mental health nursing (6th Ed.). Philadelphia: Davis Company.

Wong, D.L., Hockenberry, M., Wilson, D., Winkelstein, M.L., \& Schwartz, P. (2009). Buku ajar keperawatan pediatrik. Jakarta: EGC.

Yosep, I. (2007). Keperawatan jiwa (Cetakan pertama). Bandung: PT Refika Aditama.

Yusuf, S. (2009). Psikologi Perkembangan anak \& remaja. Bandung: PT Remaja Rosdakarya. 